\title{
Analysis of the association between Epstein-Barr virus and classic Hodgkin's lymphoma in adult patients from Ceará (Brazil) by immunohistochemistry and in situ hybridization
}

\author{
Análise da associação do vírus Epstein-Barr com a forma clássica do linfoma de Hodgkin em adultos do estado \\ do Ceará: avaliação por imuno-histoquímica e hibridização in situ
}

Marília Taumaturgo Pinto'; Francisco Valdeci de Almeida Ferreira²; Maria da Silva Pitombeira3, Silvia Maria Meira Magalhães; Clara Maria Bastos Eloy da Costa ${ }^{3}$; Paulo Wagner Linhares Lima Filho ${ }^{3}$; Renata Praciano Correia Férrer3; Andrei Levine Porfírio de Aguiar3; Francisco Dário Rocha Filho ${ }^{2}$

key words Classical Hodgkin's lymphoma Epstein-Barr virus LMP1 EBER1

\section{resumo}

The prevalence of Epstein-Barr virus (EBV) in patients with classical Hodgkin's lymphoma (CHL) is geographically variable. In the present study the prevalence of $\mathrm{EBV}$ in $\mathrm{CHL}$ was assessed in adult patients from Ceará, Brazil. Thirty-seven cases were immunohistochemically evaluated for EBV using latent membrane protein (LMP1) antibody and for EBV latency-associated RNA (EBER1) using in situ hybridization (ISH). Sex and age did not differ among patients as to the frequency of CHL. Nodular sclerosis was the predominant histological subtype. LMP1 was found in Reed-Sternberg cells in $67.5 \%$ of the cases whereas ISH detected EBER1 in 75.6\%. Regarding histological subtypes EBV infection rates were not found statistically different in nodular sclerosis (NS) and mixed cellularity (MC) subtypes ( $p=0.66$ ).

\section{abstract}

A freqüência do vírus Epstein-Barr (EBV) em pacientes com linfoma de Hodgkin Clássico ( $L H C$ ) sofre variabilidade geográfica. No presente estudo investigamos a freqüência do EBV em pacientes com LHC no estado do Ceará. Trinta e sete casos de linfoma de Hodgkin clássico foram avaliados por imuno-histoquímica para EBV usando o anticorpo monoclonal contra a proteína latente da membrana (LMP1) e pelo método de hibridização in situ para RNA associado ao EBV (EBER1). Não há diferença por sexo e idade dos pacientes no que concerne à freqüência de LHC. O subtipo histológico esclerose nodular foi predominante. LMP1 esteve presente em células Reed-Sternberg em 67,5\% e pela hibridização in situ, através da sonda EBER, foi evidente em 75,6\% dos casos. Não observamos predominância significativa da associação de EBV com os subtipos histológicos esclerose nodular (EN) e celularidade mista (CM) $(\mathrm{p}=0,66)$. unitermos

Linfoma de Hodgkin clássico

Virus Epstein-Barr

LMP1

EBER1

1. MS; Pathology Department of Universidade Estadual do Ceará (UECE).

2. PhD; Department of Pathology and Forensic Medicine (DPML) of Universidade Federal do Ceará (UFC) and Instituto do Câncer do Ceará (ICC).

3. PhD; Department of Clinical Medicine (HEMOCE/UFC).

4. Students from the Scientific Initiation Program at DPML (UFC).

This study was carried out at the Pathology Laboratory of the UFC Medical School and the ICC. The work was partially funded by CAPES and CIC. 


\section{Introduction}

The incidence of classical Hodgkin's lymphoma (CHL) varies among population groups. Nodular sclerosis (NS) subtype is the most common one in developed countries, whereas the mixed cellularity (MC) subtype is more prevalent in developing countries ${ }^{(5,10)}$. However, available data from Brazil seems to be divergent ${ }^{(2,20,21)}$.

Previous epidemiological findings suggest a relationship between classical Hodgkin's lymphoma and infection by Epstein-Barr virus $(E B V)(5,7,15,17)$. The EBV-encoded oncogene latent membrane protein (LMP1) has been consistently shown to be expressed in Reed-Sternberg cells (RS), a fact with possible implication to the pathogenesis of the disease.

In developed countries, the incidence of $\mathrm{EBV}$ in $\mathrm{CHL}$ has been found to be approximately $50 \%{ }^{(6)}$, whereas in Honduras, Peru, China and Mexico it is reported to be $100 \%, 94 \%, 61 \%$ and $67 \%$, respectively $(3,5,23,24)$.

The aim of the present study was to assess the prevalence of EBV-associated CHL of subtypes MC and NS in adult patients from the state of Ceará by immunohistochemistry (IHC) and by in situ hybridization (ISH).

\section{Methods}

Results of surgical biopsy specimens from 37 adult patients (18-64 years) with classical CHL were obtained from the files of medical institutions of Fortaleza (Ceará, Brazil) in the period 1997-2002. Thirty-seven cases with CHL were evaluated by IHC(13) for EBV, LMP1 antibody (Catalog $N^{\circ}$ M897, DakoCytomation,USA) at the dilution of 1:50, amplified by streptavidin-biotin-peroxidase technique. RNA in situ hybridization was performed to detect EBV in H-RS cells with a biotinylated probe for Epstein-Barr encoded RNAs-1 (EBER-1, Y5200-Epstein-Barr virus RNA probe/FITC, ready-to-use, DakoCytomation, USA), a viral transcript present in high levels in infected cells (about $10^{7}$ copies per nucleus) ${ }^{(22)}$. In all cases the diagnosis of CHL was confirmed by light microscopy and immunohistochemical phenotyping by two experienced hematopathologists (FVAF, FDRF). The cases were classified according to the World Health Organization Classification ${ }^{(14)}$.The panel of monoclonal antibodies included Ki-1 antigen/H-RS cells (CD30 [Catalog $N^{\circ}$ M751]), granulocyte-associated antigen/H-RS cells (CD15 [Catalog $\mathrm{N}^{\circ}$ M733]), B cells (CD20 [Catalog $\mathrm{N}^{\circ}$ MO 755]), $T$ cells associated antigen (CD3 [Catalog $N^{\circ}$ M7254]), epithelial membrane antigen (EMA [Catalog. $\mathrm{N}^{\circ}$
MO 613]) and leucocyte common antigen (CD45 [Catalog № MO701]), all from DakoCytomation,USA. As a negative control, normal mouse serum was used instead the primary antibody, followed by all other procedures.

The EBV-RNA in situ hybridization studies were performed using a 30-base oligonucleotide complementary to a segment of EBER1 gene.

Descriptive statistics and the Fisher test were used with a limit of $p<0.05$.

\section{Results}

The demographic findings showed similar numbers of men and women with similar ages among the $\mathrm{CHL}$ patients (Table 1).

The histological analysis of the samples revealed a predominance of NS subtype (62.2\%) (Table 2). The immunohistochemical and the in situ hybridization studies showed evidence of EBV respectively in $67.5 \%$ and $75.6 \%$ of the cases (Table 3). We did not find a statistically significant difference of EBV infection between NS and MC subtypes (LMP1: $p=0.66 ;$ ISH: $p=0.1$ ).

Immunophenotypic findings showed that all RS cells immuno-expressed CD30 (a criteria of inclusion), and CD15 was present in $87.8 \%$ of the cases. EBV LMP1 was detected in 25 of the 37 cases (67.5\%): 15/23 (65.2\%) of NS, 8/11 (72.7\%) of MC, $1 / 1$ (100\%) of lymphocyte depletion (LD) and $1 / 2(50 \%)$ in unclassified cases (UC) (Figure 1). There was no immunostaining of either CD3, EMA, CD45 or CD20 in RS cells.

\begin{tabular}{|c|c|c|}
\hline $\begin{array}{l}\text { Den } \\
(n=\end{array}$ & \multicolumn{2}{|c|}{$\begin{array}{l}\text { Demography of the CHL patients } \\
(n=37)\end{array}$} \\
\hline & Males & Females \\
\hline Sex & $18(48.6 \%)$ & $19(51.3 \%)$ \\
\hline Age average (years) & 30 & 32 \\
\hline
\end{tabular}

Table 2

Histological diagnosis of the CHL

Nodular sclerosis (NS)

$23(62.1 \%)$

Mixed cellularity (MC)

$11(29.7 \%)$

Lymphocyte depletion (LD)

$1(2.7 \%)$

Unclassified (UC) 
Table 3

\section{Prevalence of EBV markers in CHL} patients $(n=37)$

\begin{tabular}{lcccc}
\hline & \multicolumn{2}{c}{ LMP1 } & \multicolumn{2}{c}{ EBER1 } \\
& $25 / 37(67.5 \%)$ & \multicolumn{2}{c}{$28 / 37(75.6 \%)$} \\
& $(-/ \%)$ & $(+/ \%)$ & $(+/ \%)$ & $(-/ \%)$ \\
NS $(\mathrm{T}=23)$ & $15(65.2)$ & $8(34.8)$ & $16(69.5)$ & $7(30.4)$ \\
MC $(\mathrm{T}=11)$ & $8(72.7)$ & $3(27.2)$ & $10(90.9)$ & $1(12.5)$ \\
LD ( $\mathrm{T}=1)$ & $1(100)$ & - & $1(100)$ & - \\
(UC) $(\mathrm{T}=2)$ & $1(50)$ & $1(50)$ & $1(50)$ & $1(50)$ \\
\hline
\end{tabular}

In situ hybridization studies evidenced that patients who scored as EBV-positive showed a strong hybridization signal in the nuclei of RS and Hodgkin's cells. Twenty-eight of 37 cases (75.6\%) were positive for EBER1: 16/23 (69.5\%) of NS, 10/11 (90.9\%) of MC, $1 / 1(100 \%)$ of LD and 1/2 (50\%) of UC (Figure 2).

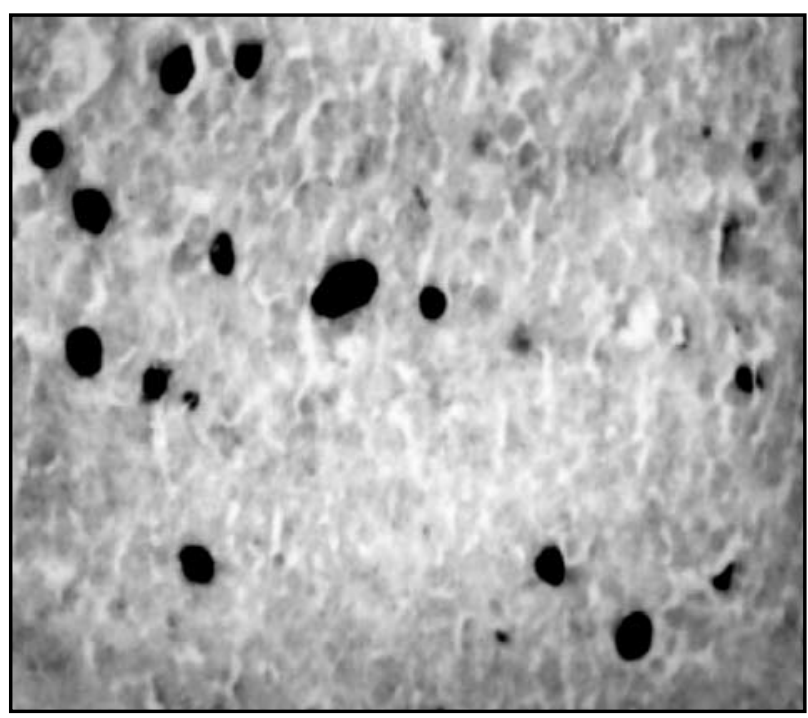

Figure 1 - Microscopic demonstration of EBV markers in classical Hodgkin's lymphoma NS-subtype by in situ hybridization (400x)

All cases with positive results by IHC were also positive by ISH. However, three negative cases for LMP1 were positive by ISH. All ISH and IHC results are summarized in Table 3.

\section{Discussion}

The prevalence of Hodgkin's lymphoma and the distribution of major subtypes have been described as variable in different populations. In developing countries, Chang et al. ${ }^{(5)}$ described a MC subtype as predominant. In the present study NS subtype was found more prevalent

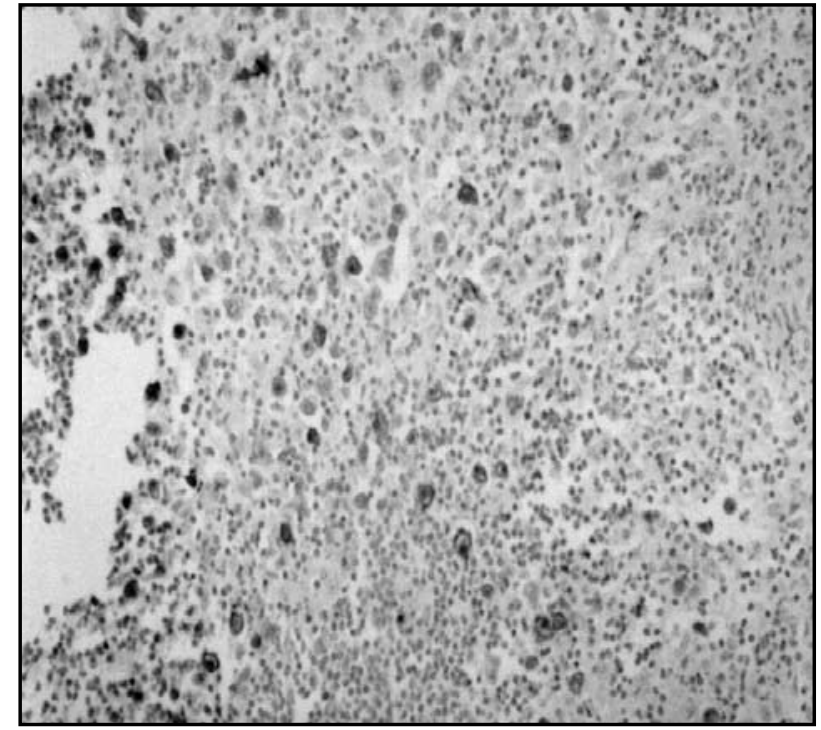

Figure 2 - Microscopic demonstration of EBV markers in classical Hodgkin's lymphoma NS-subtype by immunohistochemistry (200x)

in CHL adult patients from Ceará, contrasting to a previous study in children, in whom MC subtype predominated ${ }^{(1)}$. However, more recent unpublished findings from our laboratory show a trend for an inversion in subtypes detected in children. Remarkably, the incidence of $\mathrm{MC}$ and NS subtypes of CHL in adult patients from Ceará reported herein differs from previous studies ${ }^{(12,19)}$. The present study points to a gradual shift in prevalence, from MC to NS subtype in adult patients. This finding is in agreement with some of the recent Brazilian reports ${ }^{(2,20,21)}$. The factors responsible for this change are not well known. It is possible that changes in host response and/or living conditions resulting from investments in nutrition and health programs might have played a role on it.

In our series, the prevalence of $\mathrm{CHL}$ in males and females was not found different, as also shown in other previous studies(23).

Our results clearly agree with findings reported in literature regarding the detection of $\mathrm{EBV}$ in $\mathrm{CHL}^{(4,9-11)}$. It is possible that the higher viral load associated with the poor socioeconomic status of the patients from Ceará might be a contributing factor in worsening prognosis in $\mathrm{CHL}$. EBV was associated with $\mathrm{CHL}$ in patients from Ceará in $75.6 \%$ of cases, according to ISH results. The association between NS subtype and EBV was even higher (57.5\%) than that found for unpublished data from adult patients in several regions of France (30.3\% [data selected from the Pathology files of Laennec Hospital - Paris V University by Rocha Filho, in the period of 1997-1999). These results support the hypothesis that EBV is more frequently implicated in 
the pathogenesis of $\mathrm{CHL}$ in adult patients in Northeastern Brazil than in France. Previous studies involving patients from this Brazilian region found prevalence rates for EBV in children and adolescents as high as those of the adult patients sampled in this study ${ }^{(1)}$.

The association between EBV and CHL subtypes was found to be significantly higher in patients from Ceará (approximately 1.4 times) than that reported for patients from São Paulo ${ }^{(18)}$. In a study from Rio de Janeiro, EBV was detected in $55 \%$ of cases, its presence being significantly correlated (88\%) with the MC subtype ${ }^{(16)}$.

In agreement with previous reports ${ }^{(8)}$ the present findings suggest that LMP1 expression may be adequate for identifying EBV-associated CHL. Moreover, ISH is strongly suggested in cases with negative results, especially in $\mathrm{MC}$ subtype.

\section{Conclusions}

Results from the present study support the hypothesis that EBV is often implicated in the pathogenesis of $\mathrm{CHL}$ in adult patients from Ceará. We hypothesize that such high rates are due to a possible high EBV viral load observed in our patients, along with the early onset of $\mathrm{CHL}$ between children and adolescents, which may have contributed to the comparatively stronger association between the virus and the disease we observed. Other factors such as ethnicity, nutrition and climate might also play a role demanding further studies.

The role of EBV in $\mathrm{CHL}$ remains to be clarified, and the evaluation of the clinical implications of the presence of EBV for evolution, prognosis and pathogenesis of the disease requires further studies.

The techniques of ISH (EBER, RNA) and IHC applied to tissues fixed in formaldehyde and embedded in paraffin, as employed in our studies, may turn out to be quite valuable for future epidemiological studies on the association of EBV virus with $\mathrm{CHL}$ in other regions of Brazil.

\section{Acknowledgments}

The authors thank Carlos Mauricio de Castro Costa for the critical reading of the manuscript.

\section{References}

I.ABREU, E. S. et al. Doença de Hodgkin infanto-juvenil no estado do Ceará e sua relação com o vírus de Epstein-Barr: parâmetros clínicos e análises morfológicas imuno-histoquímica e por hibridização in situ. J Bras Patologia, v. 33, n. 4, p. 178-84, 1997.

2.ALVES,A. C. et al. Linfoma de Hodgkin: estudo interdepartamental em São Paulo com reclassificação histológica de I.044 casos: contribuição para o estudo epidemiológico no Brasil.J Bras Patologia, v. 37, n. 2, p. 9-10, 2001.

3.AMBINDER, R. F. et al. Epstein -Barr virus and childhood Hodgkin's disease in Honduras and United States. Blood, v. 8I, p. 462 7, 1993.

4. BELKAID, M. I. et al. Association du virus de Epstein-Barr à la maladie de Hodgkin: comparaison entre patients algériens et français. Bull Cancer, v. 82, p. 357-63, 1995.

5. CHANG, K. L. et al. High prevalence of Epstein-Barr virus in the Reed-Sternberg cells of Hodgkin's disease occurring in Peru. Blood, v. 8I, p. 496-50I, 1993.

6. COATES, P. J.; SLAVIN, G.; D'ARDENNE, A. J. Persistence of Epstein-Barr virus in Reed-Sternberg cells throughout the course of Hodgkin's disease. J Pathol, v. I64, p. 29|-7, 1991.

7. CORREA, P.; O'CONNOR, G.T. Epidemiologic patterns of Hodgkin's disease. Int J Cancer, v. 8, p. 192-201, I97I.

8. DELSOL, G. et al. Correlation of the expression of Epstein-Barr virus latent membrane protein and in situ hybridization with biotinylated BamHI-W probes in Hodgkin's disease. Am Pathol, v. I 40, p. 247-53, 1992.

9. DE MATEO, E. et al. Comparison of Epstein-Barr virus presence in Hodgkin's lymphoma in pediatric versus adult Argentine patients. Arch Pathol Lab Med, v. I27, p. I325-9, 2003.

10. DURMAZ, R. et al. Detection and genotyping of Epstein-Barr virus by polymerase chain reaction in tissues obtained from cases with Hodgkin's disease in Turkey. Acta Virol, v. 42, n. 6 , p. 375-8, 1998

I I. EVANS, A. S.;GUTENSOHN, N. M. A population-based casecontrol study of EBV and other viral antibodies among persons with Hodgkin's and their siblings. Int J Cancer, v. 34, p. 149-57, 1984

12. FERREIRA, F.V. A.; OLIVEIRA, E. G.; ALENCAR, J. E. B. Doença de Hodgkin: peculiaridades estatísticas em Fortaleza, Ceará Brasil. Rev Med Univ Fed Ceará, v. 17, p. I5-8, 1977.

13. HSU, S. M.; RAINE, L.; FANGER, H. Use of avidin-biotin-peroxidase complex $(A B C)$ in immunoperoxidase techniques: a comparison between $\mathrm{ABC}$ and unlabeled (PAP) procedures. J Histochem Cytochem, v. 29, p. 577-80, 1981.

14. JAFFE, E. S. et al. World Organization Classification of Tumors. Pathology and Genetics. Tumors of hematopoietic and lymphoid tissues. Lyon, 200I. Cap. 8, p. 239-53.

15.JARRET,A. F;:ARMSTRONG,A.A.;ALEXANDER, E. Epidemiology 
of EBV and Hodgkin's lymphoma. Ann Oncology, v. 7, Suppl. 4, S5-SI0, 1996.

16. LOUREIRO, M. M. et al. Expression of Epstein-Barr virus in patients with Hodgkin's disease: report of 64 cases from Rio de Janeiro, Brazil.J Bras Patol, v. 40, n. I, p. 37-40, 2004.

17. MACMAHON, B. Epidemiology of Hodgkin's disease. Cancer Res, v. 26, p. I I89-2000, 1966.

I 8. OLIVEIRA, E.D.;BACCHI,M.M.;ABREU, E.S. et al.Hodgkin's disease in adult and juvenile groups from two different geographic regions in Brazil: characterization of clinicopathologic aspects and relationship with Epstein-Barr virus infection. Am J Clin Pathol, v. I I 8, p. 25-30, 2002.

19. PITOMBEIRA, M. S.; FERREIRA, F.V., MARTINS, J. M. Doença de Hodgkin- I. Perfil histopatológico no estado do Ceará. Rev Med Fed Ceará, v. XXII, p. 19-21, 1981.
20.VASSALLO,J. et al. Expression of Epstein-Barr in classical Hodgkin's lymphomas in Brazilian adult patients. Haematologica, v. 86 n. II, p. |227-28, 2001.

2I. VASSALLO, J. et al. Further remarks on the expression of CD20 in classical Hodgkin's lymphomas. Haematologica, v. 87, ELTI7, 2002

22.WEISS, L. M. et al. Epstein-Barr virus and Hodgkin's disease. Am J Pathol, v. 139, p. 1259-65, I991.

23. ZARATE-OSORNO, A. et al. Hodgkin's disease in Mexico. Prevalence of Epstein-Barr virus sequences and correlations with histologic subtype. Cancer, v. 75, p. 1360-6, 1995.

24. ZHOU, X. G. et al. Epstein-Barr virus (EBV) in Chinese pediatric Hodgkin disease: Hodgkin disease in young children is an EBV-related lymphoma. Cancer, v. 92, n. 6, p. |62|-3|, 200| 